\section{Nitrate-N Concentrations in the Soil Solution Below Reuse Irrigated Golf Course Fairways}

\author{
Dale A. Devitt ${ }^{1}$ and Lena Wright
}

School of Life Sciences, University of Nevada-Las Vegas, 4505 Maryland Parkway, Las Vegas, NV 89154

Daniel C. Bowman

Department of Plant Science, North Carolina State University, Raleigh, NC 27695

Robert L. Morris

Cooperative Extension, University of Nevada-Reno, 8050 South Maryland

Parkway, Suite 100, Las Vegas, NV 89123-0855

\section{Michelle Lockett}

Water Resource Management, University of Nevada-Las Vegas, 4505 Maryland Parkway, Las Vegas, NV 89154

Additional index words. leaching fractions, bermudagrass, fertilizer-N, reuse-N

Abstract. Irrigators in arid and semiarid regions that use reuse water must maintain positive leaching fractions (LFs) to minimize salt buildup in root zones. However, with the continuous feed of $\mathrm{NO}_{3}-\mathrm{N}$ in reuse water, imposing LFs can also lead to greater downward movement of $\mathrm{NO}_{3}-\mathrm{N}$. It is therefore essential that deep movement of $\mathrm{NO}_{3}-\mathrm{N}$ be assessed relative to nitrogen loading under such conditions. We conducted a long-term monitoring program on nine golf course fairways in southern Nevada over a 1600d period. The fairways were predominantly bermudagrass [Cynodon Dactylon (L.) Pers.; 35 of 36 site $\times$ years] overseeded with perennial ryegrass (Lolium perenne L.; 8 of 9 courses). Courses were irrigated with fresh water, reuse water (tertiary treated municipal sewage effluent), or transitioned to reuse water during the study. Solution extraction cups were inserted at depths of $15,45,75$, and $105 \mathrm{~cm}$ on fairways and sampled and analyzed for $\mathrm{NO}_{3}-\mathrm{N}$ on a monthly basis. Distribution patterns of $\mathrm{NO}_{3}-\mathrm{N}$ varied from site to site. Concentrations exceeding $100 \mathrm{mg} \cdot \mathrm{L}^{-1}$ were observed at the $105-\mathrm{cm}$ depth on all three long-term reuse courses. On the transitional courses, $72 \%$ of the variation in the yearly average $\mathrm{NO}_{3}-\mathrm{N}$ concentrations at the $105-\mathrm{cm}$ depth could be accounted for based on knowing the amount of fertilizer nitrogen $(N)$ applied, the amount of reuse $N$ applied, and the $\operatorname{LF}(\mathrm{Y}=-\mathbf{4 2 . 5}+0.18$ fertilizer $\mathrm{N}+0.26$ reuse $\mathrm{N}-\mathbf{6 2 . 0} \mathrm{LF})$. Highest $\mathrm{N}$ fertilizer applications occurred on transition courses with little or no reduction in $\mathrm{N}$ applications after courses had transitioned to reuse water (pretransition courses $394+247 \mathrm{~kg} \cdot \mathrm{ha}^{-1} \mathrm{~N} /$ year versus posttransition courses $\left.398+226 \mathrm{~kg} \cdot \mathrm{ha}^{-1} \mathrm{~N} / \mathrm{year}\right)$. The results of this study indicate a need for a more scientific approach to $\mathrm{N}$ management on reuse irrigated courses. is an environmentally preferred alternative to discharging such waters back into rivers and lakes. However, care must be taken when irrigating with reuse water because it carries a significant salt and nitrogen load. Although the nitrogen load should be viewed as a positive trait for turfgrass managers, it does mean that conventional applications of nitrogen must be properly adjusted. Nitrogen concentrations typically remain fairly high on a year-round basis in reuse water (Feigin et al., 1991). Thus, as irrigation levels go up in the summer months, so does the nitrogen loading. Bermudagrass in particular is known for its high nitrogen uptake rates (Bowman et al., 2006; Feigin et al., 1991; Fonseca et al., 2007; Olsen and Kurtz, 1982). If irrigations are excessive, nitrate-nitrogen is prone to leaching (Brown et al., 1982; Devitt et al., 1976; Feigin et al., 1991; Letey et al., 1977; Snyder et al., 1981). However, many turfgrass studies under fresh water irrigation have reported low nitrate-nitrogen $\left(\mathrm{NO}_{3}-\mathrm{N}\right)$ leaching, especially with bermudagrass (Snyder et al., 1984, Wu et al., 2007), whereas Bowman et al. (2006) found that under various levels of stress, nitrogen $(\mathrm{N})$ use efficiency declined for several turfgrass species, leading to elevated $\mathrm{N}$ leaching losses. Regulatory agencies such as the Nevada Department of Environmental Protection require quarterly reporting of the amount of reuse water used and the amount of $\mathrm{N}$ applied. Irrigating with waters that have elevated salinity levels requires that a leaching fraction be incorporated into the longterm irrigation management plan. Because irrigation systems do not deliver water in a perfectly uniform fashion, irrigation must be applied at a rate beyond actual evapotranspiration to compensate for this nonuniformity while also achieving acceptable leaching. In Las Vegas, NV, a minimum leaching fraction of 0.15 associated with yearly soil sampling to assess salt buildup is recommended. In a previous study (Devitt et al., 2007), we reported that only four of nine golf courses
Many golf courses in the southwestern United States are transitioning to reuse water for irrigation purposes. In Las Vegas, NV, 30 of 53 golf courses now irrigate with reuse water. As communities grow in size, the amount of reuse water generated also increases (Devitt et al., 2007). Using reuse water for golf courses and urban landscapes

Received for publication 20 June 2008. Accepted for publication 11 Aug. 2008.

We thank the Southern Nevada Water Authority for their financial support of this research. We also thank Mr. Gary Grinnell of the Las Vegas Valley Water District and Dr. Joseph Leising of SNWA for technical advisement. Finally, we thank Polly Conrad and Brian Bird for their able field and laboratory assistance.

${ }^{1}$ To whom reprint requests should be addressed; e-maildev50@clark.nscee.edu
Table 1. Site characteristics.

\begin{tabular}{|c|c|c|c|c|}
\hline $\begin{array}{l}\text { Golf } \\
\text { course }\end{array}$ & $\begin{array}{l}\text { Irrigation } \\
\text { status }\end{array}$ & $\begin{array}{c}\text { Electrical } \\
\text { conductivity } \\
\text { of water }\left(\mathrm{dSm}^{-1}\right)\end{array}$ & $\begin{array}{c}\mathrm{NO}_{3}-\mathrm{N} \text { water } \\
\left(\mathrm{mg} \cdot \mathrm{L}^{-1}\right)\end{array}$ & Turfgrass $^{y}$ \\
\hline$\overline{\mathrm{P}}$ & Fresh & 0.80 & $0.5 \pm 0.6$ & Common bermudagrass \\
\hline B & Reuse & 2.00 & $11.8 \pm 10.6$ & Common bermudagrass \\
\hline $\mathrm{L}$ & Reuse & 2.07 & $10.6 \pm 8.7$ & Tifway hybrid bermudagrass \\
\hline W & Reuse & 2.22 & $14.0 \pm 4.7$ & $\begin{array}{l}\text { Tifway hybrid bermudagrass base and } \\
\text { common bermudagrass }\end{array}$ \\
\hline A & Transition & $0.98 / 1.51^{\mathrm{z}}$ & $0.5 \pm 0.6 / 6.9 \pm 4.8$ & $\begin{array}{l}\text { Common bermudagrass } \\
\text { base plus annual bluegrass }\end{array}$ \\
\hline $\mathrm{C}$ & Transition & $0.95 / 1.40$ & $0.4 \pm 0.6 / 3.2 \pm 2.5$ & Tifway hybrid bermudagrass \\
\hline $\mathrm{R}$ & Transition & $0.99 / 1.40$ & $1.0 \pm 2.1 / 5.2 \pm 0.8$ & $\begin{array}{l}\text { Blend of } 50 \% \text { Palmer perennial ryegrass, } \\
50 \% \text { Prelude perennial ryegrass (2001); } \\
\text { NuMex Sahara } \\
\text { common bermudagrass }(2002-2004)\end{array}$ \\
\hline $\mathrm{S}$ & Transi & $0.95 / 1.46$ & $0.4 \pm 0.6 / 3.2 \pm 2.5$ & Tifway hybrid bermudagrass \\
\hline $\mathrm{T}$ & Transition & $0.89 / 1.42$ & $0.3 \pm 0.4 / 6.9 \pm 4.8$ & Tifway hybrid bermudagrass \\
\hline
\end{tabular}

${ }^{\mathrm{z}}$ Fresh water/reuse water.

${ }^{y}$ Common bermudagrass [Cynodon dactylon (L.) Pers.]; Hybrid bermudagrass [Cynodon dactylon (L.) Pers. $\times$ Cynodon transvaalensis Burtt-Davy]; Perennial ryegrass (Lolium perenne L.); Annual bluegrass (Poa annua L.). All courses except transition course T overseeded with perennial ryegrass in the fall of each year. 
monitored maintained positive field-based leaching fractions (LFs) in all 4 years. Irrigators must maintain a delicate balance between maintaining favorable salt balances while minimizing $\mathrm{NO}_{3}-\mathrm{N}$ leaching. Because of environmental concerns over the fate of $\mathrm{N}$ in reuse water applied to golf courses, we measured $\mathrm{NO}_{3}-\mathrm{N}$ concentrations in the soil solution at four depths on a monthly basis over a 1600 -d period. Results reported here are part of a larger study (Devitt et al., 2004, 2005, 2007). The objectives of this phase of the study were to 1) compare and contrast the $\mathrm{NO}_{3}-\mathrm{N}$ concentrations below reuse irrigated fairways with fairways that transitioned to reuse water; and 2) determine if fundamental relationships existed among the amount of $\mathrm{N}$ applied (reuse $\mathrm{N}$ plus fertilizer $\mathrm{N}$ ), the $\mathrm{LF}$, and the $\mathrm{NO}_{3}-\mathrm{N}$ concentrations in the soil solution.

\section{Material and Methods}

A reuse study was initiated in 2000 on nine golf courses (Table 1) located in the Las Vegas Valley: three long-term reuse courses (designated as $\mathrm{B}, \mathrm{L}$, and $\mathrm{W}$ ), three freshwater courses (designated as $\mathrm{P}, \mathrm{R}$, and $\mathrm{T}$ ), and three courses identified to transition to reuse water during the monitoring period (designated as $\mathrm{A}, \mathrm{C}$, and S). However, because the Colorado River basin was experiencing an extended drought, two of the fresh water courses ( $\mathrm{R}$ and $\mathrm{T}$ ) also transitioned during the latter part of this study. Results reported in this phase of the experiment relate directly to $\mathrm{NO}_{3}-\mathrm{N}$ concentrations monitored with depth on the fairways of all nine golf courses. Companion papers report on irrigation water quality (Devitt et al., 2005), spatial distribution of surface salts (Devitt et al., 2007), and plant response (Lockett, 2008).

Reuse water used on the golf courses all originated from municipal tertiary treated wastewater facilities. In the case of reuse courses B and L, reuse water was delivered from the city of Henderson treatment facility, whereas course $\mathrm{W}$ received water from the Clark County treatment facility. However, transition courses received water from satellite treatment facilities (municipal tertiarytreated). Transition courses A, C, and T all received water from the Durango Hills water resource center, whereas courses $\mathrm{S}$ and $\mathrm{R}$ received water from the Desert Breeze water resource center.

To collect soil solution, extraction cups (Soil Moisture Corp., Santa Barbara, CA) were installed on a fairway of each golf course. Soil classification for fairway soils is reported in Table 2. Solution cups were installed in a nested vertical array positioned at depths of $15,45,75$, and 105 $\mathrm{cm}$. However, as a result of caliche and rock layers at some courses, not all extraction cups could be placed at the $105-\mathrm{cm}$ depth. Soil solution was vacuum-extracted from the soil profile on a monthly basis. Overflow and cross contamination was prevented by placing a 4-L reservoir in line between the vacuum tank and the collection vials.

Table 2. Soil classification for fairways.

\begin{tabular}{ll}
\hline Course & \multicolumn{1}{c}{ Description } \\
\hline A & Cave gravelly fine sandy loam (loamy, mixed, thermic, shallow Typic Paleorthids) \\
B & Arizo very gravelly fine sandy loam (sandy-skeletal, mixed, thermic Typic Torriorthents) \\
C & Cave gravelly fine sandy loam (loamy, mixed, thermic, shallow Typic Paleorthids) \\
L & Arizo extremely stony loam (sandy-skeletal, mixed, thermic Typic Torriorthents) \\
P & Glen carb very fine sandy loam (fine-silty, carbonatic, thermic Typic Torrifluvents) \\
R & Cave gravelly fine sandy loam (loamy, mixed, thermic, shallow Typic Paleorthids) \\
S & Cave gravelly fine sandy loam (loamy, mixed, thermic, shallow Typic Paleorthids) \\
T & Cave gravelly fine sandy loam (loamy, mixed, thermic, shallow Typic Paleorthids) \\
W & McCarran fine sandy loam (coarse-loamy, mixed, thermic Cambic Gypsiorthids) \\
\hline
\end{tabular}

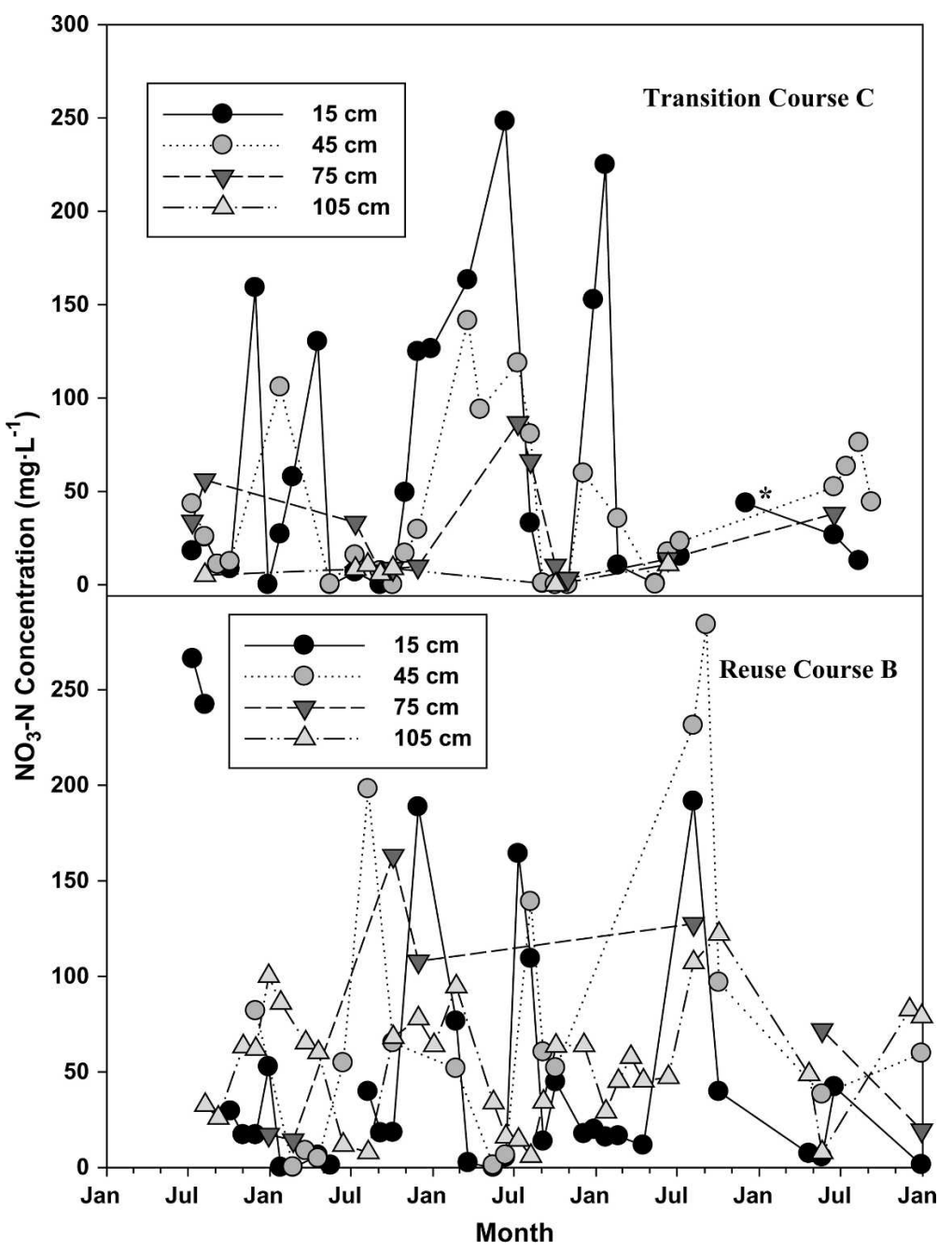

Fig. 1. $\mathrm{NO}_{3}-\mathrm{N}$ concentration with depth on a fairway for transition course $\mathrm{C}$ and long-term reuse course $\mathrm{B}$ over the 1600-d monitoring period. Asterisk denotes date of transition.

The tank and collection system were left running overnight on collection days. Samples were picked up before golf play the next morning and immediately capped and placed on ice. All collection vials and tubing were triple-rinsed with distilled water and dried before the next sampling. At the laboratory, the samples were divided into scintillation vials and frozen if not run for nitrates on the same day. Samples were analyzed for nitrates and ammonium (not reported as a result of few samples exceeding the detection limit) on a Timberline TL-550-A Conductivity detector (Timberline Instruments, Boulder, $\mathrm{CO}$ ) and checked using a Dionex DX-120 Ion
Chromatograph (Dionex Corporation, Sunnyvale, CA). All courses were monitored for the entire1600-d experimental period.

Irrigation was estimated from volume (water meter) precipitation curves established for each site. Evapotranspiration was estimated by using locally derived crop coefficients (Kc) (Devitt et al., 1992) and potential evapotranspiration estimates (PenmanMonteith Equation; Campbell Scientific, Logan, UT) from local automated weather stations. Irrigation system uniformities (Christiansen Uniformity Coefficients; Hart and Reynolds, 1965) were evaluated for each fairway before initiation of the study using a 
Table 3. Average yearly $\mathrm{NO}_{3}-\mathrm{N}$ concentrations $\left(\mathrm{mg} \cdot \mathrm{L}^{-1}\right)$ with standard deviations (SD) at the 15-, 45-, 75-, and 105-cm depths.

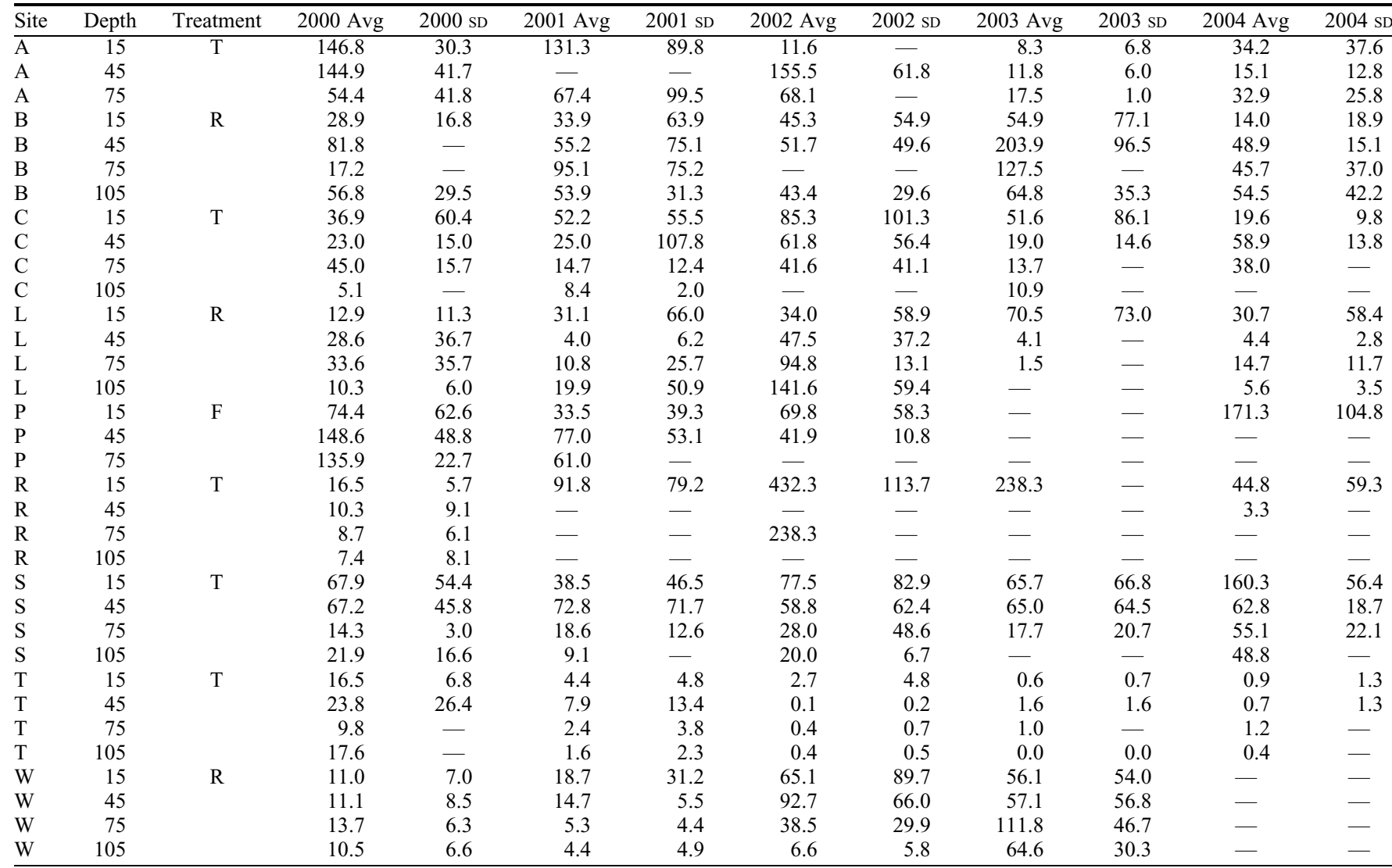

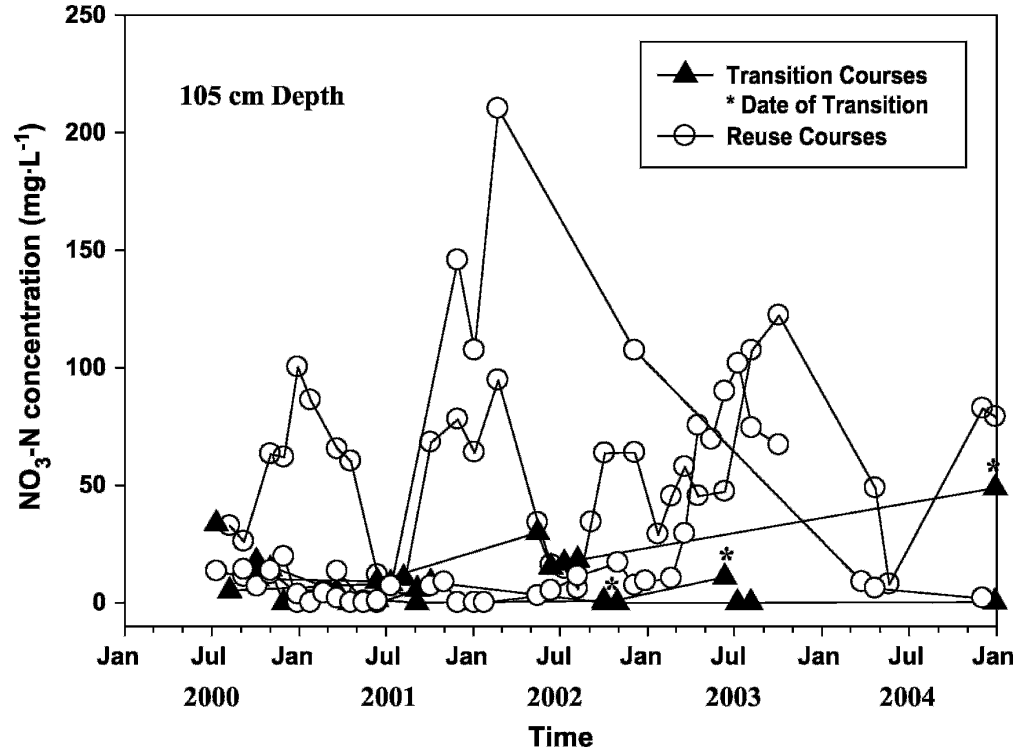

Fig. 2. $\mathrm{NO}_{3}-\mathrm{N}$ concentration at $105-\mathrm{cm}$ depth for transition and reuse courses over the $1600-\mathrm{d}$ monitoring period.

$5 \times 5$ grid of cups in the irrigation cell containing the sensor location (Devitt et al., 2007).

The LF, which estimates the percentage of irrigation water that drains below a root zone, defined as the drainage volume divided by the irrigation volume was indirectly estimated for all fairways by defining LF as [irrigationevapotranspiration $\left.\left(\mathrm{ET}_{\mathrm{o}} \times \mathrm{Kc}\right)\right]$ /irrigation where the numerator assumes that the difference between the irrigation applied and an estimate of actual ET would adequately predict drainage when based on yearly time periods. These estimates are referred to as "field-based" measurements because they do not take into consideration how the irrigation is actually distributed on the scale that exists between each and every sprinkler head. To assess actual LFs at a specific site within a field (which will vary based on the uniformity of the irrigation system) requires the instal- lation of drainage flux meters or nonweighing lysimeters or the use of an indirect approach such as the use of chloride ratios. Because chloride is a conservative anion and moves freely with soil water, if steady-state conditions exist [chloride $(\mathrm{Cl})$ in irrigation water $*$ volume of irrigation water $=\mathrm{Cl}$ in drainage water $*$ volume of drainage water], the ratio of the drainage volume to the irrigation volume (LF) can be assessed by analyzing the ratio of $\mathrm{Cl}$ in the drainage water to the $\mathrm{Cl}$ in the irrigation water. Las Vegas receives $\approx 10 \mathrm{~cm}$ of rainfall yearly compared with the total irrigation on a typical golf course of greater than $180 \mathrm{~cm}$. Thus, if estimates are made before any change in water quality, $\mathrm{Cl}$ concentrations in the irrigation water will vary little over time. Finally, the assumption was made that soil solution samples evacuated at a depth of $105 \mathrm{~cm}$ would reflect the drainage and that steady-state conditions existed during defined periods of time (validated by assessing the $\mathrm{Cl}$ concentration with depth). LFs using both approaches were used in assessing $\mathrm{NO}_{3}-\mathrm{N}$ movement.

Data were analyzed using descriptive analysis and linear and multiple regression analysis. Multiple regressions were performed in a backward stepwise manner with deletion of terms occurring when $P$ values for the $t$ test exceeded 0.05 . To eliminate the possibility of cocorrelation, parameters were included only if variance inflation factors (VIFs) were less than 3 and the sum total was less than 10. If the accepted VIF was 
exceeded, parameters were eliminated and regressions were run a second time.

\section{Results}

Nitrate-N concentrations as well as soluble salt concentrations varied in the reuse water based on transitional courses receiving reuse water from satellite treatment plants and long-term reuse courses receiving reuse water directly from the main treatment plants. Satellite treatment plants blended reuse water with municipal water to meet the irrigation demands during peak summer months; thus, the concentrations were lower (Table 1). However, it should be noted that significant temporal variability also existed with the $\mathrm{NO}_{3}-\mathrm{N}$ concentrations in the reuse water generated from the main treatment plants (coefficient of variation range, 0.34 to 0.90 ).

Nitrate-N concentrations in the soil solution with depth are plotted in Figure 1 for transitional course $\mathrm{C}$ and long-term reuse course B for comparative purposes. Nitrate$\mathrm{N}$ concentrations approached or exceeded $250 \mathrm{mg} \cdot \mathrm{L}^{-1}$ at the shallowest depths at both courses. Greatest oscillations occurred at the 15-cm depth with lower concentrations and more subtle oscillations at the greater depths (Fig. 1). Although vacuum extraction did not always generate soil solution samples, a relatively good picture of distribution with depth and time were achieved at most courses (Table 3 ). $\mathrm{NO}_{3}-\mathrm{N}$ concentrations at most sites revealed a decreasing trend with depth. Exceptions to this trend were observed on course R in 2002 and course B in 2004. When yearly average $\mathrm{NO}_{3}-\mathrm{N}$ concentrations were high at the $45-\mathrm{cm}$ depth, they were also high at the $75-\mathrm{cm}$ depth $\left[45 \mathrm{~cm} \mathrm{NO}_{3}-\mathrm{N}=11.69+\right.$ $\left.0.92\left(75 \mathrm{~cm} \mathrm{NO}_{3}-\mathrm{N}, R^{2}=0.50^{* * *}\right)\right]$. However, high concentrations at the 75-cm depth were not associated with similar high concentrations at the $105-\mathrm{cm}$ depth when all data were merged $\left[105 \mathrm{~cm} \mathrm{NO}_{3}-\mathrm{N}=5.67+1.35\right.$ $\left(75 \mathrm{~cm} \mathrm{NO}_{3}-\mathrm{N}\right)-0.0054\left(75 \mathrm{~cm} \mathrm{NO}_{3}-\mathrm{N}\right)^{2}$, $\left.R^{2}=0.70^{* * *}\right]$. Where sampling allowed, a clear distinction was observed in $\mathrm{NO}_{3}-\mathrm{N}$ concentrations at the $105-\mathrm{cm}$ depth when transition courses were contrasted with reuse courses over the 1600-d monitoring period (Fig. 2). The deepest extraction cups did not always collect leachate, especially compared with the near surface samplers at $15 \mathrm{~cm}$. Nitrate-N concentrations at the $105-\mathrm{cm}$ depth on reuse courses exceeded $100 \mathrm{mg} \cdot \mathrm{L}^{-1}$ on all three courses, exceeding $200 \mathrm{mg} \cdot \mathrm{L}^{-1}$ on one of the three courses, whereas transition courses typically had $\mathrm{NO}_{3}-\mathrm{N}$ concentrations below $25 \mathrm{mg} \cdot \mathrm{L}^{-1}$ (Fig. 2). On the transitional courses, $72 \%$ of the variation in the yearly average $\mathrm{NO}_{3}-\mathrm{N}$ concentrations at the $105-\mathrm{cm}$ depth could be accounted for based on knowing the amount of fertilizer $\mathrm{N}$ applied, the amount of reuse $\mathrm{N}$ applied, and the LF $(\mathrm{Y}=-42.5+0.18$ fertilizer $\mathrm{N}+0.26$ reuse $\mathrm{N}-62.0 \mathrm{LF})$. As the field-based LF increased, the predicted $\mathrm{NO}_{3}-\mathrm{N}$ concentration decreased.

When $\mathrm{NO}_{3}-\mathrm{N}$ concentrations at the 105$\mathrm{cm}$ depth on reuse course $\mathrm{B}$ were plotted along with irrigation volumes over the exper- imental period, an inverse relationship was observed with higher concentrations of $\mathrm{NO}_{3}-\mathrm{N}$ associated with lower irrigation volumes (Fig. 3). However, this relationship broke down during the fourth summer when higher concentrations were associated with higher irrigation volumes. Seasonal patterns were also observed at the other sites, although not always as well defined as in the case of reuse course B.

Although the highest $\mathrm{NO}_{3}-\mathrm{N}$ concentrations at the $105-\mathrm{cm}$ depth were associated

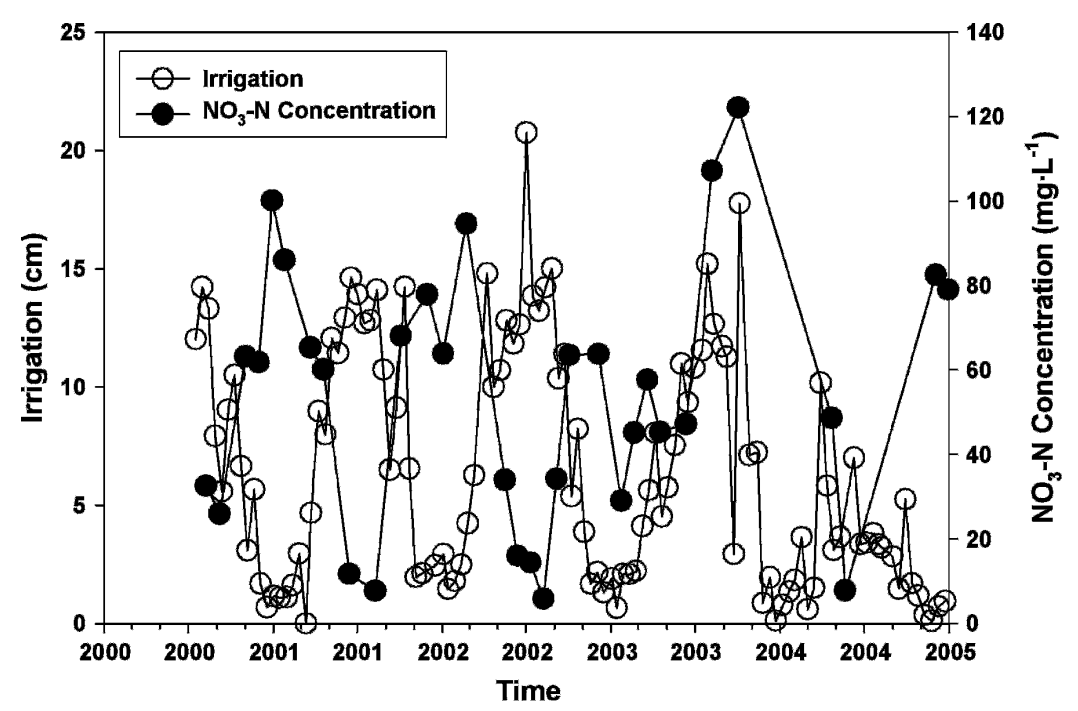

Fig. 3. Irrigation applied $(\mathrm{cm})$ and $\mathrm{NO}_{3}-\mathrm{N}$ concentration at $105-\mathrm{cm}$ depth over the $1600-\mathrm{d}$ monitoring period.

Table 4. Nitrogen application by fertilizer and reuse water, irrigation volume, and field-based leaching fraction (LF) on a yearly basis.

\begin{tabular}{|c|c|c|c|c|c|c|}
\hline Year & $\begin{array}{l}\text { Course/ } \\
\text { treatment }\end{array}$ & $\begin{array}{l}\text { Fertilizer N } \\
\left(\mathrm{kg} \cdot \mathrm{ha}^{-1} / \mathrm{yr}\right)\end{array}$ & $\begin{array}{c}\text { Reuse N } \\
\left(\mathrm{kg} \cdot \mathrm{ha}^{-1} / \mathrm{yr}\right)\end{array}$ & $\begin{array}{c}\text { Total N } \\
\left(\mathrm{kg} \cdot \mathrm{ha}^{-1} / \mathrm{yr}\right)\end{array}$ & $\begin{array}{c}\text { Irrigation } \\
\text { volume }(\mathrm{cm})\end{array}$ & LF \\
\hline 2001 & $\mathrm{~A} / \mathrm{T}$ & 549.0 & 8.0 & 557.0 & 132.0 & 0.05 \\
\hline $2002^{y}$ & & 369.0 & 81.2 & 450.2 & 123.8 & -0.26 \\
\hline 2003 & & 574.5 & 60.2 & 634.7 & 119.2 & -0.27 \\
\hline 2004 & & 440.2 & 55.8 & 496.0 & 95.8 & -0.33 \\
\hline 2001 & $\mathrm{~B} / \mathrm{R}$ & 259.7 & 299.7 & 559.4 & 156.4 & 0.20 \\
\hline 2002 & & 258.4 & 235.5 & 493.9 & 201.1 & 0.20 \\
\hline 2003 & & 257.6 & 192.7 & 450.2 & 189.6 & 0.21 \\
\hline 2004 & & 258.1 & 219.1 & 477.2 & 153.0 & 0.16 \\
\hline 2001 & $\mathrm{C} / \mathrm{T}$ & 341.7 & 11.0 & 352.7 & 166.5 & 0.25 \\
\hline 2002 & & 536.9 & 12.9 & 549.9 & 211.0 & 0.26 \\
\hline 2003 & & 341.6 & 3.0 & 344.6 & 169.8 & 0.11 \\
\hline $2004 *$ & & 538.4 & 85.1 & 623.5 & 138.3 & 0.08 \\
\hline 2001 & $\mathrm{~L} / \mathrm{R}$ & 180.3 & 356.0 & 536.3 & 182.8 & 0.31 \\
\hline 2002 & & 77.6 & 217.6 & 295.1 & 238.1 & 0.34 \\
\hline 2003 & & 278.8 & 82.1 & 360.9 & 213.0 & 0.29 \\
\hline 2004 & & 212.5 & 254.4 & 466.9 & 204.2 & 0.38 \\
\hline 2001 & $\mathrm{P} / \mathrm{F}$ & 302.6 & 6.5 & 309.1 & 121.0 & -0.04 \\
\hline 2002 & & 217.3 & 8.5 & 225.7 & 141.0 & -0.12 \\
\hline 2003 & & 260.1 & 3.5 & 263.6 & 138.8 & -0.09 \\
\hline 2004 & & 260.1 & 1.0 & 261.1 & 108.8 & -0.17 \\
\hline 2001 & $\mathrm{R} / \mathrm{T}$ & - & 13.9 & - & 222.5 & 0.37 \\
\hline 2002 & & $1,124.9$ & 15.9 & $1,140.8$ & 278.4 & 0.36 \\
\hline 2003 & & 544.3 & 16.4 & 560.7 & 304.4 & 0.45 \\
\hline $2004 *$ & & 832.3 & 146.4 & 978.7 & 232.5 & 0.40 \\
\hline 2001 & $\mathrm{~S} / \mathrm{T}$ & 353.9 & 9.0 & 362.8 & 136.0 & 0.08 \\
\hline 2002 & & 366.1 & 10.0 & 376.1 & 174.0 & 0.09 \\
\hline 2003 & & 155.2 & 2.5 & 157.7 & 135.0 & -0.11 \\
\hline $2004 *$ & & 334.1 & 67.2 & 401.3 & 108.8 & -0.12 \\
\hline 2001 & $\mathrm{~T} / \mathrm{T}$ & 170.8 & 3.0 & 173.8 & 113.7 & -0.11 \\
\hline $2002 *$ & & 171.0 & 58.7 & 229.7 & 145.8 & -0.10 \\
\hline 2003 & & 124.1 & 105.1 & 229.1 & 191.2 & 0.21 \\
\hline 2004 & & 203.6 & 81.7 & 285.3 & 142.4 & 0.11 \\
\hline 2001 & $\mathrm{~W} / \mathrm{R}$ & 345.6 & 204.6 & 550.2 & 111.4 & -0.13 \\
\hline 2002 & & 321.8 & 235.5 & 557.3 & 134.2 & -0.18 \\
\hline 2003 & & 367.7 & 91.6 & 459.4 & 120.0 & -0.26 \\
\hline 2004 & & 345.1 & 177.2 & 522.3 & 153.3 & 0.20 \\
\hline
\end{tabular}

Irrigation treatment.

${ }^{\mathrm{y}}$ Year course transitioned to reuse water.

$\mathrm{T}=$ transition course; $\mathrm{R}=$ reuse course $; \mathrm{F}=$ fresh course. 
with reuse courses, we have limited data to suggest that these higher concentrations may reflect a concentration effect. When the yearly average $\mathrm{NO}_{3}-\mathrm{N}$ concentration at $105-\mathrm{cm}$ depth was plotted as a function of the leaching fraction, which was estimated based on chloride ratios $(\mathrm{Cl}$ concentration in irrigation water divided by the $\mathrm{Cl}$ concentration in the soil solution at $105 \mathrm{~cm}$ ), a linear relationship was found (yearly average $\mathrm{NO}_{3}-\mathrm{N}=145$ to $\left.809 \mathrm{LF}, R^{2}=0.62 *\right)$. The LF estimated was made on the transition courses just before switching to reuse water and the LF estimated on the reuse courses was estimated at the end of the monitoring period, which maximized the time for possible steady-state conditions to exist. It should be noted that LF based on the $\mathrm{Cl}$ ratios differed from the field-based estimates (Table 4). This was expected because the Christiansen Uniformity Coefficient for the irrigation systems ranged from 0.77 to 0.92 (Devitt et al., 2007). Only on two of the courses would LFs appear to be excessive on a field basis (courses L and R) with five of the nine courses reporting their lowest LFs during the fourth and final year (a response associated with the extended drought conditions). The Cl-based LF was more reflective of site-specific leaching associated with the $\mathrm{NO}_{3}-\mathrm{N}$ monitoring. As the $\mathrm{LF}$ declined from 0.17 to 0.05 , the predicted yearly average $\mathrm{NO}_{3}-\mathrm{N}$ concentration rose from 8 to $105 \mathrm{mg} \cdot \mathrm{L}^{-1}$.

Amounts of $\mathrm{N}$ fertilizer applied to the fairways were obtained from the golf course superintendents on a monthly basis and are reported as yearly totals in Table 3 . Annual amounts ranged from a low of $78 \mathrm{~kg} \cdot \mathrm{ha}^{-1} \mathrm{~N} /$ year on the reuse course L to a high of 1125 $\mathrm{kg} \cdot \mathrm{ha}^{-1} \mathrm{~N} /$ year on transition course R. Nitrogen applied through the application of reuse water was estimated by weighting irrigation volumes obtained from bimonthly water meter readings with monthly concentrations of $\mathrm{NO}_{3}-\mathrm{N}$ analyzed in the reuse water. $\mathrm{N}$ loading (Table 4) from the irrigation water before transitioning to reuse water was low, ranging from 3.0 to $16 \mathrm{~kg} \cdot \mathrm{ha}^{-1} \mathrm{~N} /$ year. However, $\mathrm{N}$ loading through reuse water on transitional courses ranged from 56 to $146 \mathrm{~kg} \cdot \mathrm{ha}^{-1} \mathrm{~N} / \mathrm{year}$ and on long-term reuseirrigated courses, $\mathrm{N}$ loading ranged from 82 to $356 \mathrm{~kg} \cdot \mathrm{ha}^{-1} \mathrm{~N} /$ year.

When yearly average $\mathrm{NO}_{3}-\mathrm{N}$ concentrations on transition courses were plotted as a function of either the total $\mathrm{N}$ applied (75 and $105 \mathrm{~cm})$ or the fertilizer $\mathrm{N}$ applied $(15 \mathrm{~cm})$, highly significant linear or curvilinear relationships were revealed $(P<0.001)$ (Fig. 4). At the deepest depth, the slope of the curve became extremely steep after $400 \mathrm{~kg} \cdot \mathrm{ha}^{-1}$ per year of total $\mathrm{N}$ was applied, suggesting a possible threshold. However, at the shallowest depth, the relationship was correlated not with total $\mathrm{N}$, but with fertilizer $\mathrm{N}$, reflecting the influence of the shorter travel times for fertilizer $\mathrm{N}$, which was applied as individual pulses versus the continuous feed of $\mathrm{NO}_{3}-\mathrm{N}$ in the reuse water.

Finally, we assessed whether fertilizer N was being reduced based on the additional $\mathrm{N}$
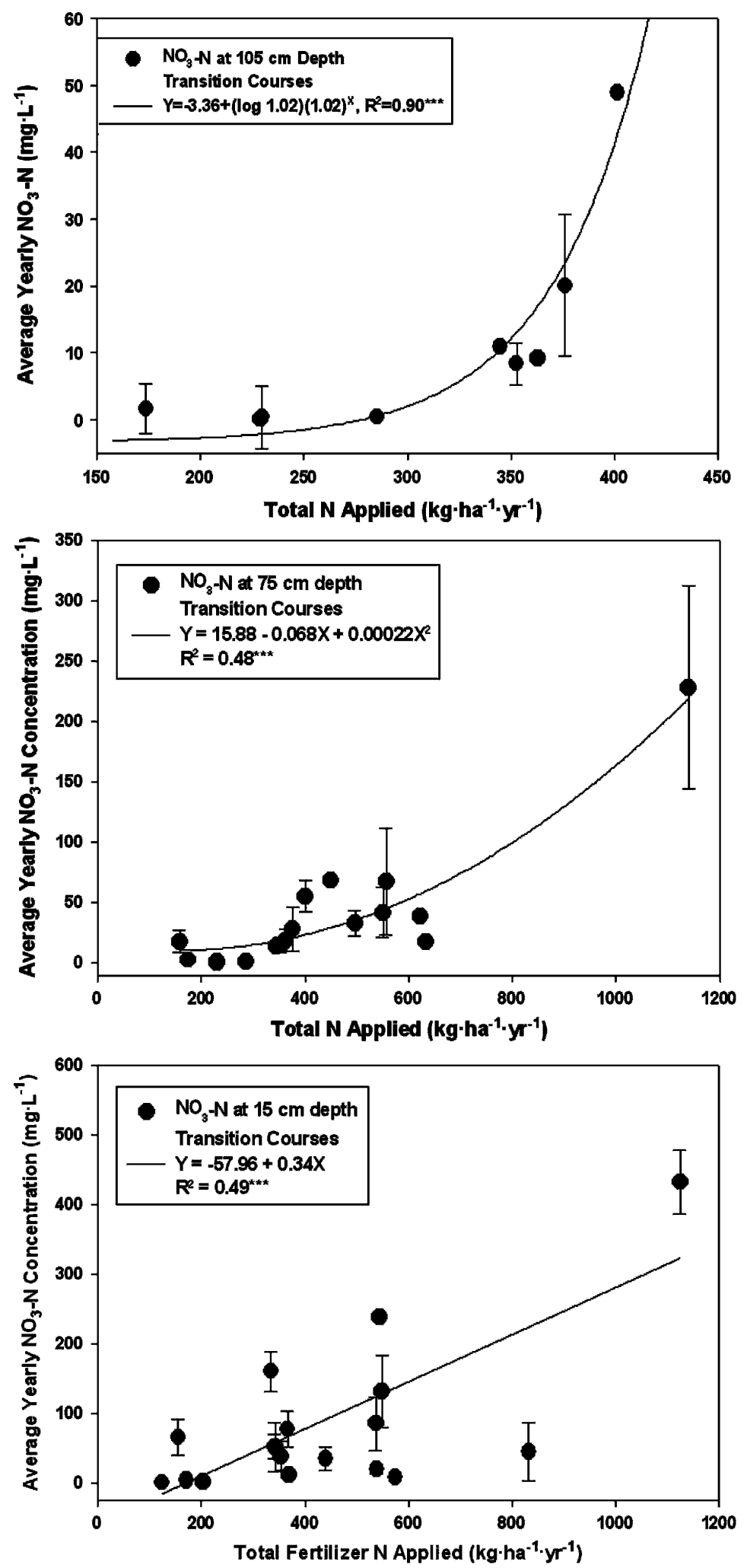

Fig. 4. Average yearly $\mathrm{NO}_{3}-\mathrm{N}$ concentration at $15-\mathrm{cm}$ depth versus total fertilizer nitrogen applied and average yearly $\mathrm{NO}_{3}-\mathrm{N}$ concentration at 75 - and $105-\mathrm{cm}$ depth versus total nitrogen applied.

loading through the reuse water (Fig. 5). Although the relationship was not significant $(P=0.136)$, an inverse linear trend was observed. Highest $\mathrm{N}$ fertilizer applications occurred on transition courses with little or no reduction after courses had transitioned to reuse water (pretransition courses $394+247$ $\mathrm{kg} \cdot \mathrm{ha}^{-1} \mathrm{~N} /$ year versus posttransition courses $398+226 \mathrm{~kg} \cdot \mathrm{ha}^{-1} \mathrm{~N} /$ year). Although the fertilizer amount applied to reuse courses $\left(256+81 \mathrm{~kg} \cdot \mathrm{ha}^{-1} \mathrm{~N} /\right.$ year $)$ was not significantly different from the transitional courses, the average value and SD were lower, suggesting a possible directional shift in $\mathrm{N}$ 


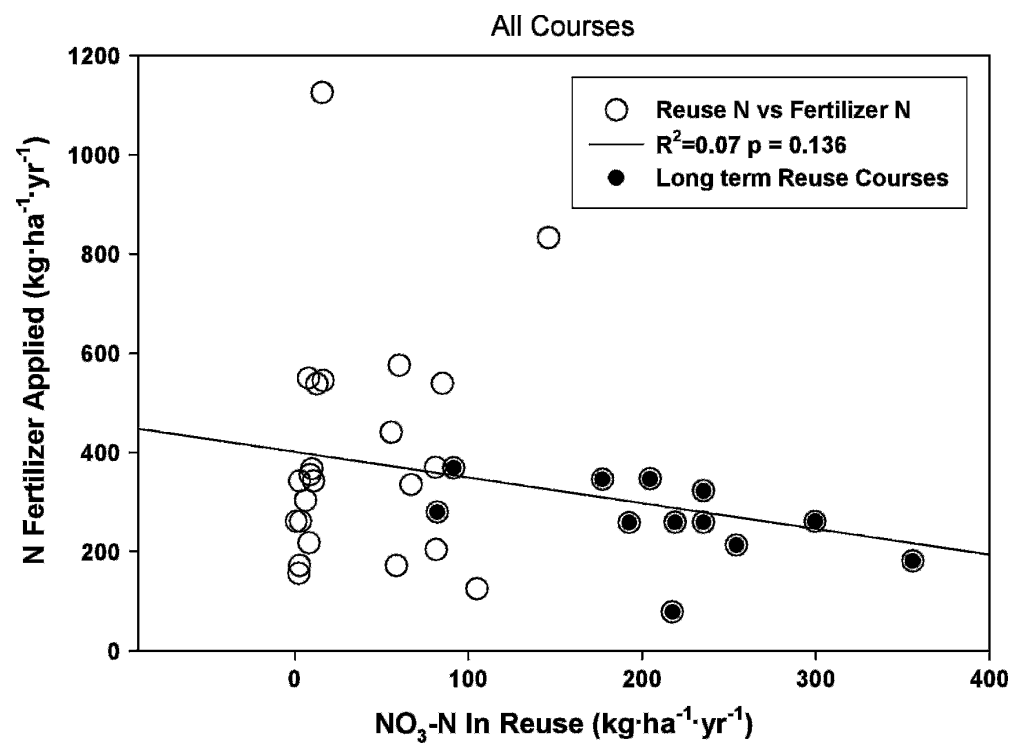

Fig. 5. Nitrogen fertilizer applied versus $\mathrm{NO}_{3}-\mathrm{N}$ in reuse water applied through irrigation.

management being imposed. Additional studies incorporating a larger data set will be needed to address this issue and verify changes in $\mathrm{N}$ management.

\section{Discussion}

Using reuse water for the irrigation of golf courses is recognized as an acceptable and beneficial use by the Environmental Protection Agency (EPA, 1992). However, it is also recognized by both federal and state regulatory agencies that nitrates in the reuse water can pose an environmental risk (Nevada Division of Environmental Protection, 2007). Results published from both conventional agricultural studies and turfgrass studies indicate that the main driving forces behind $\mathrm{NO}_{3}-$ $\mathrm{N}$ leaching losses are directly related to the specific characteristics of the soil-plant system and the fertilizer and irrigation timing and amounts (Anderson et al., 1981; Devitt et al., 1976; Feigin et al., 1991; Letey et al., 1977). It is therefore not surprising to find a wide range in the published concentrations of $\mathrm{NO}_{3}-\mathrm{N}$ in leachate draining below plant root systems (Anderson et al., 1981; Bowman et al., 1998, 2006; Brown et al., 1982; Kopp and Guillard, 2005; Mancino and Troll, 1990; Snyder et al., 1984; Wu et al., 2007). Although several turfgrass studies have documented $\mathrm{NO}_{3}-\mathrm{N}$ movement associated with fertilization (Brown et al., 1982; Snyder et al., 1984), we are unaware of any other studies that have documented concentrations as high as those measured in this study, i.e., $\mathrm{N}$ loading resulting from both fertilizer applications and reuse water applied for irrigation.

Clearly, the continual feeding of nutrients such as $\mathrm{NO}_{3}-\mathrm{N}$ in irrigation water is problematic, because applications often do not coincide with plant needs and the $\mathrm{NO}_{3}-\mathrm{N}$ often remains in a more mobile phase. In contrast, fertilizer granules undergo solubilization, diffusion, and leaching with fertilization events often spaced at intervals greater than a month (Brown et al., 1982; Mancino and Troll, 1990; Snyder et al., 1984). Under golf course irrigated conditions in Las Vegas, $\mathrm{NV}$, irrigation water is typically applied four to seven times per week during peak summer months; thus, little dry down occurs that might enhance the capillary attractiveness of $\mathrm{NO}_{3}-\mathrm{N}$ to micropores (Kirkham, 2005).

Significant salt movement from shallower depths to deeper depths was previously reported during winter months (Devitt et al., 2007), so it was not surprising to see similar movement for $\mathrm{NO}_{3}-\mathrm{N}$. Anderson et al. (1981) also reported seasonal effects on $\mathrm{NO}_{3}-\mathrm{N}$ concentration with lower values during the winter months. This displacement, we believe, was achieved because of additional water applied during the overseeding period. This water was partitioned differently allowing for a greater percentage of the applied water to contribute to a larger drainage component. This was accelerated as a result of lower consumptive use because the bermudagrass base was entering dormancy while the overseeded ryegrass was germinating and establishing a shallow root system. This conclusion is supported by the work of Bowman et al. (1998) who demonstrated that rooting architecture/depth affected $\mathrm{NO}_{3}-\mathrm{N}$ leaching. We also cannot rule out the contribution of macropore bypass (Barton et al., 2005; McLeod et al., 1998) that would be maximized under such conditions, which may have contributed to the breakdown in the seasonal response in some years.

Concentrations of $\mathrm{NO}_{3}-\mathrm{N}$ are of course not the entire story when it comes to assessing environmental risk. Although regulatory agencies have set $\mathrm{NO}_{3}-\mathrm{N}$ standards for drinking water at $10 \mathrm{mg} \cdot \mathrm{L}^{-1}$, concentrations beyond that level do not in themselves dictate that a serious environmental threat is occurring. Instead, environmental threat must be assessed based on mass loading, which means concentrations must be weighted with appropriate drainage fluxes. Although $\mathrm{NO}_{3}-\mathrm{N}$ concentrations were often high under the golf course fairways in this study, LF estimated at the monitoring sites was relatively low $(0.05$ to 0.17 ) with an inverse relationship between yearly average $\mathrm{NO}_{3}-\mathrm{N}$ concentrations and $\mathrm{LF}$. However, the fact that $\mathrm{NO}_{3}-\mathrm{N}$ concentrations at the $105-\mathrm{cm}$ depth were significantly higher under reuse-irrigated fairways than transitional fairways remains a concern. Results from this study suggest that deep $\mathrm{NO}_{3}-\mathrm{N}$ movement may be associated with total $\mathrm{N}$ loading in excess of $400 \mathrm{~kg} \cdot \mathrm{ha}^{-1}$ per year, as suggested by Figure 4 . In 10 of the possible 12 site-years on the reuse-irrigated courses, total $\mathrm{N}$ applied exceeded $400 \mathrm{~kg} \cdot \mathrm{ha}^{-1}$ per year.

The fact that transitional courses made no significant adjustment in $\mathrm{N}$ fertilization after switching to reuse water indicates a need for expanded educational programming in this area. However, it is also apparent that realtime water quality data are needed by the superintendents, perhaps in a web-based format, which would allow the superintendents to make more accurate adjustments in $\mathrm{N}$ fertilization based on $\mathrm{N}$ loading in the reuse water. Future research is needed to develop more accurate $\mathrm{N}$ and irrigation management strategies associated with the irrigation of reuse water. This is especially true for the southwestern United States where adequate leaching is critical for maintaining favorable salt balances, but also enhances the movement of nutrients such as $\mathrm{NO}_{3}-\mathrm{N}$. We remain supportive of the use of reuse water for the irrigation of golf courses, but also recognize the need for a more scientific approach to $\mathrm{N}$ management on such courses.

\section{Literature Cited}

Anderson, E.L., I.L. Pepper, and W.R. Kneebone. 1981. Reclamation of wastewater with a soil turf filter: 1: Removal of nitrogen. Journal WPCF 53:1402-1407.

Barton, L., L.A. Schipper, G.F. Barkle, M. McLeod, T.W. Speir, M.D. Taylor, A.C. McGill, A.P. Van Schaik, N.B. Fitzgerald, and S.P. Pandey. 2005. Land application of domestic effluent onto four soil types: Plant uptake and nutrient leaching. J. Environ. Qual. 34:635-643

Bowman, D.C., D.A. Devitt, M.C. Engelke, and T.W. Rufty, Jr. 1998. Root architecture affects nitrate leaching from bentgrass turf. Crop Sci. 38:1633-1639.

Bowman, D.C., D.A. Devitt, and W.W. Miller. 2006. The effect of moderate salinity on nitrate leaching from bermudagrass turf: A lysimeter study. Water Air Soil Pollut. 175:49-60.

Brown, K.W., J.C. Thomas, and R.L. Duble. 1982 Nitrogen source effect on nitrate and ammonium leaching and runoff losses from greens. Agron. J. 74:947-950.

Devitt, D.A., J. Letey, L.J. Lund, and J.W. Blair 1976. Nitrate-nitrogen movement through soil as affected by soil profile characteristics. J. Environ. Qual. 5:283-288.

Devitt, D.A., M. Lockett, R.L. Morris, and B.M Bird. 2007. Spatial and temporal distribution of salts on fairways and greens irrigated with reuse water. Agron. J. 99:692-700. 
Devitt, D.A., R.L. Morris, M. Baghzouz, and M. Lockett. 2005. Water quality changes in golf course irrigation ponds transitioning to reuse water. HortScience 40:2151-2156.

Devitt, D.A., R.L. Morris, and D.C. Bowman. 1992. Evapotranspiration, crop coefficients and leaching fractions of irrigated desert turfgrass systems. Agron. J. 88:844-849.

Devitt, D.A., R.L. Morris, D. Kopec, and M. Henry. 2004. Golf course superintendent's attitudes and perceptions toward using reuse water for irrigation in the southwestern United States. HortTechnology 14:1-7.

EPA. 1992. Guidelines for water reuse. EPA/625/ R-92/004.

Feigin, A., I. Ravina, and J. Shalhevet. 1991. Irrigation with treated sewage effluent: Management for environmental protection. SpringerVerlag, Berlin, Germany.

Fonseca, A.F., A.J. Melfi, F.A. Monteiro, C.R. Montes, V.V. Almeida, and U. Herpin. 2007. Treated sewage effluent as a source of water and nitrogen for Tifton 85 bermudagrass. Agr. Water Mgt. 87:328-336.
Hart, W.E. and W.N. Reynolds. 1965. Analytical design of sprinkler systems. Trans. ASAE 8: 83-89.

Kirkham, M.B. 2005. Principles of soil and plant water relations. Elsevier Academic Press, New York, NY, 500 pages.

Kopp, K.L. and K. Guillard. 2005. Clipping contributions to nitrate leaching from creeping bentgrass under varying irrigation and $\mathrm{N}$ rates. Int. Turfgass Soc Res J. 10:80-85.

Letey, J., J.W. Blair, D. Devitt, L.S. Lund, and P. Nash. 1977. Nitrate-nitrogen in effluent from agricultural tile drains in California. Hilgardia 45:289-319.

Lockett, M. 2008. Quantifying the impact of reuse water on the soil and turfgrass quality of golfcourses. Water resource management. University of Nevada Las Vegas, MS Thesis.

Mancino, C.F. and J. Troll. 1990. Nitrate and ammonium leaching losses from $\mathrm{N}$ fertilizers applied to 'Pencross' Creeping Bentgrass. HortScience 25:194-196.

McLeod, M., L.A. Schipper, and M.D. Taylor. 1998. Preferential flow in a well drained and a poorly drained soil under different overhead irrigation regimes. Soil Use and Management 14:96-100.

Nevada Division of Environmental Protection. 2007. Dec. 2007. <http://ndep.nv.gov/index. htm>.

Olsen, R.A. and L.T. Kurtz. 1982. Crop nitrogen requirements, utilization and fertilization, p. 597-604. In: Stevenson, F.J., (ed.). Nitrogen in agricultural soils. Amer. Soc, Agron.

Snyder, G.H., B.J. Augustin, and J.M. Davidson. 1984. Moisture sensor-controlled irrigation for reducing $\mathrm{N}$ leaching in bermudagrass turf. Agron. J. 76:964-969.

Snyder, G.H., E.O. Burt, and J.M. Davidson. 1981. Nitrogen leaching in bermudagrass turf: 2 . Effect of nitrogen sources and rates, p. 313324. In: Sheard, R.W. (ed.). Proc. 4th Int. Turfgrass Res. Conf., University of Guelph, Ontario, Canada, 1980.

Wu, L., R. Green, M.V. Yates, P. Pacheco, and G. Klein. 2007. Nitrate leaching in overseeded bermudagrass fairways. Crop Sci. 47:25212528 . 